\title{
Ptk7 and Mcc, Unfancied Components in Non-Canonical Wnt Signaling and Cancer
}

\author{
Norris Ray Dunn ${ }^{1}$ and Nicholas S. Tolwinski ${ }^{2,3, *}$ \\ 1 Agency for Science Technology and Research (A*STAR) Institute of Medical Biology, 8A Biomedical Grove, \\ \#06-06 Immunos, Singapore 138648, Singapore; ray.dunn@imb.a-star.edu.sg \\ 2 Division of Science, Yale-NUS College, Singapore 138610, Singapore \\ 3 Department of Biological Sciences, Centre for Translational Medicine, NUS Yong Loo Lin School of Medicine, \\ National University of Singapore, 14 Medical Drive, Level 10 South, 10-02M, Singapore 117599, Singapore \\ * Correspondence: Nicholas.Tolwinski@yale-nus.edu.sg; Tel.: +65-6601-3092
}

Academic Editors: Renée van Amerongen and Walter Birchmeier

Received: 20 May 2016; Accepted: 7 July 2016; Published: 16 July 2016

\begin{abstract}
Human development uses a remarkably small number of signal transduction pathways to organize vastly complicated tissues. These pathways are commonly associated with disease in adults if activated inappropriately. One such signaling pathway, Wnt, solves the too few pathways conundrum by having many alternate pathways within the Wnt network. The main or "canonical" Wnt pathway has been studied in great detail, and among its numerous downstream components, several have been identified as drug targets that have led to cancer treatments currently in clinical trials. In contrast, the non-canonical Wnt pathways are less well characterized, and few if any possible drug targets exist to tackle cancers caused by dysregulation of these Wnt offshoots. In this review, we focus on two molecules-Protein Tyrosine Kinase 7 (Ptk7) and Mutated in Colorectal Cancer (Mcc) - that do not fit perfectly into the non-canonical pathways described to date and whose roles in cancer are ill defined. We will summarize work from our laboratories as well as many others revealing unexpected links between these two proteins and Wnt signaling both in cancer progression and during vertebrate and invertebrate embryonic development. We propose that future studies focused on delineating the signaling machinery downstream of Ptk7 and Mcc will provide new, hitherto unanticipated drug targets to combat cancer metastasis.
\end{abstract}

Keywords: Wnt; Ptk7; Mcc; PCP; cancer

\section{Introduction}

Human cancer is often caused by mutations in genes that regulate embryonic development and adult homeostasis. Many of these genes are part of an intricate network of signals controlling cellular behavior throughout the complex process of embryogenesis. One such signal, involved in a variety of contexts, is known as the Wnt signaling pathway [1-5]. Wnt ligands transmit signals from cell to cell across membranes to regulate gene expression and protein localization [6,7]. Too much, or too little, Wnt leads to developmental defects and/or disease. Many aspects of Wnt polarity pathways and their function in generating cellular asymmetry are understood, but the basic cell biology of how these secreted ligands influence cell shape and cell movement remains unclear [8-10]. Most importantly, the combination of cell movement and growth is the basis of metastasis and tumor invasiveness [11].

Members of the Wnt family of secreted glycoproteins play evolutionarily conserved roles in establishing embryonic axes and in lineage specification during gastrulation [8]. Significantly, Wnts are also iteratively used beyond development and function prominently in adult tissue homeostasis. For example, a class of Wnts commonly referred to as "canonical" require $\beta$-catenin for their intracellular signal transduction, and these ligands play well-established roles in the maintenance of 
stem cell niches [10]. Of clinical significance, Wnt pathway dysregulation in these niches is intimately associated with tumorigenesis. Probably the most famous example is the hereditary colon cancer known as Familial Adenomatous Polyposis (FAP), which results from germline mutations in the Adenomatous Polyposis Coli (APC) gene [12]. In the absence of Wnt stimulation, APC (and other proteins: Axin, GSK-3, Figure 1) form a destruction complex that normally targets $\beta$-catenin for ubiquitylation. In FAP patients, loss of APC results in constitutive activation of the Wnt/ $\beta$-catenin pathway and adenoma formation [13,14]. Generally, the mechanism of canonical Wnt signal transduction is based on phosphorylation and ubiquitin-mediated degradation of $\beta$-catenin, ensuring low levels of cytoplasmic of $\beta$-catenin and preventing its entry into the nucleus (Figure 1A). Upon Wnt ligand binding, an activation complex forms at the membrane preventing $\beta$-catenin degradation, allowing its protein levels to increase and translocation into the nucleus where it functions as a transactivator along with the transcription factor TCF (Figure 1B).

A second class of Wnts, aptly called "non-canonical", engage diverse and less well characterized signal transduction pathways that do not employ $\beta$-catenin [15-17]. In a number of model systems, non-canonical Wnts have been shown to control epithelial apico-basal cell polarity (asymmetry within individual cells), cell organization within the plane of a tissue (so-called planar cell polarity or PCP), and cell migration during morphogenetic processes [18,19]. In contrast to canonical Wnts, they are unable to transform cells when overexpressed, and consequently their role in cancer was not immediately apparent. Wnt ligands can work as directional cues setting up asymmetry within a tissue or a cell [20,21]. Very recently, however, Wnt/PCP signaling pathway components-ligands, receptors, co-receptors and intracellular effectors-have been linked to tumor invasion and metastasis [22-24]. One recent example of this was the finding that autocrine Wnt-PCP signaling stimulated the motility and protrusion of breast cancer cells through endosomes loaded with Wnt11, leading to metastasis [25].

The best characterized, although not without its controversies, is the planar PCP pathway that organizes wing hairs and ommatidial orientation in Drosophila [15]. The vertebrate equivalents are also well studied, but fall into several pathways that may not be independent of each other $[26,27]$. Such is the variety and interplay between these pathways that a recent opinion piece, echoing a much earlier paper [28], suggested that non-canonical signaling could be viewed as a network of differing, cell-specific effects rather than as distinct linear pathways [29]. The PCP pathway mechanism is complex and described extensively elsewhere $[19,26,30]$, but the very broad mechanism for Wnt-polarity pathways includes the cytoplasmic protein Disheveled indirectly activating small GTPases leading to cytoskeletal and adhesive changes in cells (Figure 1C, [27]). This review focuses on two proteins that do not fit the standard non-canonical signaling pathways: Protein tyrosine kinase 7 (Ptk7) and the multiple PDZ domain protein, Mutated in colorectal cancer (Mcc).
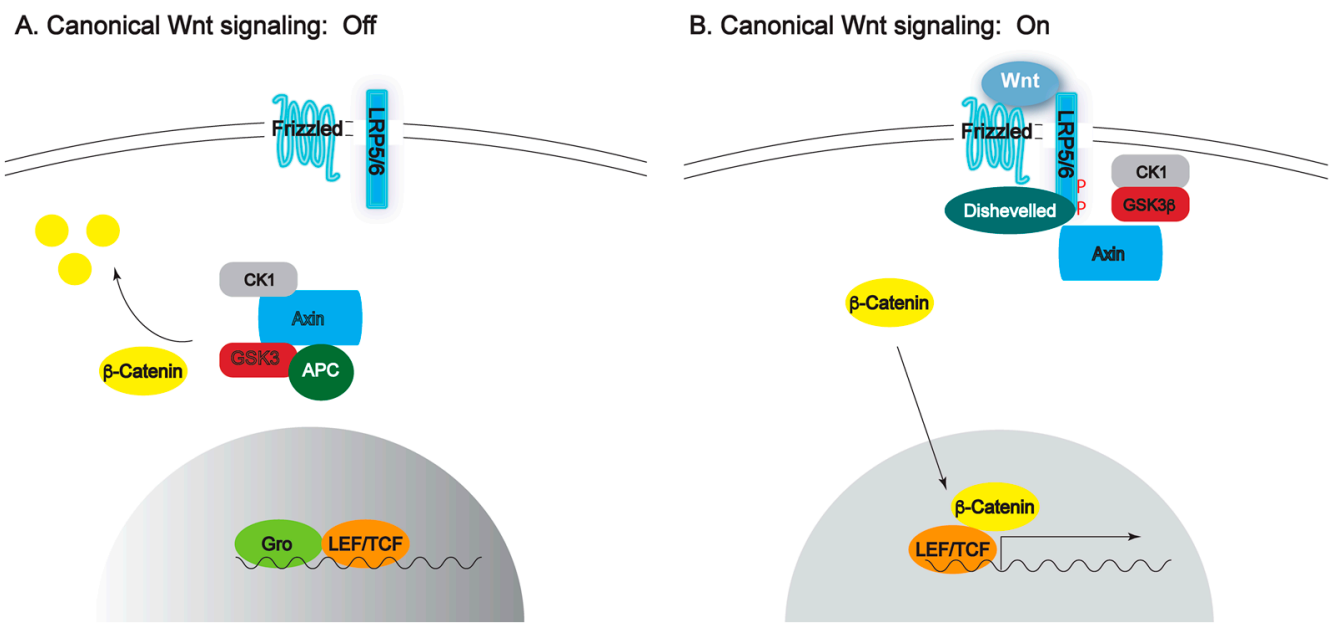

Figure 1. Cont. 


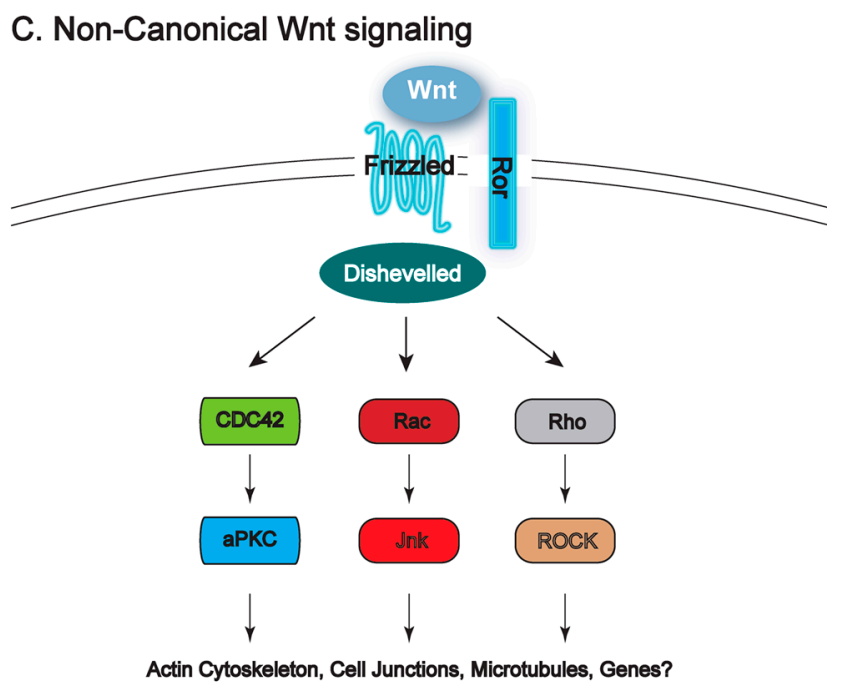

Figure 1. A schematic representation of the Wnt pathway in off (A) and on (B) conformations and the non-canonical Wnt pathway (C). (A) In the absence of Wnt ligand, the destruction complex forms in the cytoplasm bringing together APC and Axin, and presenting $\beta$-catenin for phosphorylation by CK1 and GSK3. Phosphorylated $\beta$-catenin is ubiquitylated and degraded by the proteasome, and does not enter the nucleus where gene expression is repressed by TCF in complex with the repressor Groucho/TLE; (B) Upon Wnt ligand binding, the activation complex forms at the membrane where the kinase activity of CK1 and GSK3 is redirected toward LRP5/6 in complex with Axin and Dsh. $\beta$-catenin is no longer phosphorylated, enters the nucleus, and takes part in transcription along with TCF; (C) The non-canonical Wnt pathway uses a variety of transmembrane proteins like Ror to affect cellular polarity both within the plane of the tissue (PCP) or even within the cell (apico-basal polarity). Figure was adapted from Schlesinger et al. [27].

\section{The Transmembrane Receptor Ptk7}

Ptk7 is a single-pass transmembrane Wnt/PCP co-receptor known to control cell migration and polarity in the fly, chicken, frog, zebrafish and mouse embryos [31], and recently was found to affect regeneration in planarians [32]. In Drosophila, the Ptk7 orthologue off-track (otk) was discovered as a neuronal pathfinding molecule. Otk associates with Plexin A to transduce a repulsive signal from Semaphorin 1a. Loss of Otk protein leads to embryonic axon guidance defects in the central nervous system and in motor neuron projections [33], as well as inappropriate photoreceptor cell connectivity in the fly eye [34,35].

The human Otk orthologue was originally named Colon Carcinoma Kinase 4 (CCK4), a gene highly upregulated in colon cancers, but was renamed Protein Tyrosine Kinase 7 (Ptk7) because its protein structure places it among a single-pass transmembrane receptor family with a deficient kinase domain [36,37]. Early studies examined Ptk7 expression in a variety of cancers, and revealed that Ptk7 levels are higher in lung, colon and gastric cancers and are associated with poor prognosis and higher metastatic potential [38-43]. In contrast, $P t k 7$ is downregulated in some subtypes of ovarian cancers and melanomas [44,45], but not other ovarian cancer subtypes [46]. Ptk7 has additionally been linked to breast cancer [47-49] and leukemia [50-53]. Recently, Ptk7 was implicated in cancer cell motility and metastasis in fibrosarcoma HT1080 cells, identified as a potential diagnostic biomarker for a variety of cancer types [54-62], and proposed as a tumor suppressor gene by inhibiting ERK and AKT phosphorylation in lung cancer [39].

An embryonic role for Ptk7 was first discovered through a gene trap screen for mouse mutations affecting neural development [63], and has subsequently been linked to human neural tube defects [64]. Loss of Ptk7 resulted in neural tube closure and cochlear cell rotation defects, both considered classic mouse PCP phenotypes [30,65]. In Xenopus, targeting Ptk7 transcripts with antisense 
morpholino oligonucleotides resulted in convergence and extension defects during gastrulation [63]. Convergence and extension is a morphogenetic process consisting of a specialized set of mass cellular rearrangements that simultaneously narrows the body axis mediolaterally and elongates it from head to tail. Subsequently, it was shown that mouse and zebrafish embryos also require Ptk7 for proper convergence and extension movements [66,67]. The Ptk7 gene has been implicated in idiopathic scoliosis in a zebrafish model, where it appears to be required for directional cerebrospinal fluid flow regulated by ciliated cells [68,69]. In addition, much like the invertebrate function of Otk, in vertebrate development, Ptk7 interacts with plexin A1 regulating neural crest migration [70-72]. Ptk7 is cleaved by a membrane type matrix metalloprotease (MT1-MMP) affecting its function in both zebrafish and human development, and cancer cell metastasis [61,73-76]. Taken together, these findings suggest that Ptk7 is a highly regulated, polarity-determining molecule in a variety of cellular behaviors both during development and in cancers.

Recent work also revealed a strong link between Ptk7 and a variety of stem cell functions. For example, antibodies to the extracellular domain of Ptk7 can be used to isolate human colonic stem cells directly from patient samples, and importantly these cells are similar to LGR5+ gut stem cells [42]. Another study showed that mice lacking Ptk7 had decreased pools of hematopoietic stem cells [77]. Taken together, these findings emphasize that Ptk7 plays critical roles not only during embryonic development but also in the maintenance of tissue homeostasis and cancer. Thus, one pressing experimental need is to identify the signals operating upstream of the Ptk7 transmembrane receptor and to determine how Ptk7 relays these extracellular signals intracellularly to coordinate such diverse processes $[8,10,78]$.

\section{Ptk7 and Wnt Signaling}

The Wnt oncogene was originally identified as an integration site for mouse mammary tumor virus more than thirty years ago $[9,79,80]$. Upregulation of Int-1 as it was known then caused mammary tumors, launching a field of basic research that defined the canonical Wnt pathway. More recently, several Wnt signaling pathways that function to generate different cellular outcomes have been discovered [2-4]. Wnt pathways affect polarity, stem cell maintenance and asymmetric cell division, cell growth and proliferation, differentiation, and apoptosis [3,27,78]. Non-canonical Wnts have been scrutinized for their role in cancer progression and metastasis (reviewed in [11,17,81]). Since all of these processes affect human health, much work has focused on differentiating one type of signaling from another, leading to a major biological question of how Wnt proteins can elicit such different outcomes in cells? There is great interest in this topic, as new Wnt pathway based therapies are being developed targeting specific cancers [82], but these could have inadvertent side effects by affecting other crucial systems such as stem cell maintenance.

The discovery of Wnt co-receptors allowed the assorted non-canonical Wnt signaling pathways to be teased apart. These co-receptors show different affinities for different Wnt ligands, and elicit distinct cellular outcomes [83-86]. For example, the Wnt5-Derailed (Ryk in vertebrates) system regulates Drosophila embryonic axon guidance, whereas Eg120 (Wnt)-Ror in C. elegans organizes cells during oogenesis. Both examples show how discrete Wnt-co-receptors, either Derailed/Ryk or Ror, activate non-canonical signaling pathways $[87,88]$. The model then claims that the specific co-receptor recruited upon Wnt ligand binding activates a specific cellular pathway by engaging different intracellular signaling molecules $[89,90]$. This model requires a number of different co-receptors with different affinities for different Wnt ligands. Otk serves such a role as it specifically binds to Drosophila Wnt4 [91] and Wnt2 [92]. Xenopus Ptk7 selectively interacts with Wnt3a and Wnt8 [91]. This interaction requires Frizzled 7 (Fzd7), suggesting that Fzd7 is a Ptk7 co-receptor. Both Ptk7 and Otk oppose canonical $\beta$-catenin-dependent signaling during Drosophila and Xenopus embryonic development [91,93]. Mutations in Ptk7 have been implicated in mouse neural tube closure defects [63], and loss of function mutations in Zebrafish show defects in axial convergence and extension, and neural tube morphogenesis [67]. Ptk7 also binds to the non-canonical ligand Wnt5a leading to Jnk activation 
and morphogenetic cell rearrangements [94]. Wnt5a and Ptk7 mutant mice show very similar intestinal phenotypes, suggesting a mechanism where the non-canonical Wnt5a signals through Ptk7-expressing intestinal epithelial cells (Figure 2 [95]).

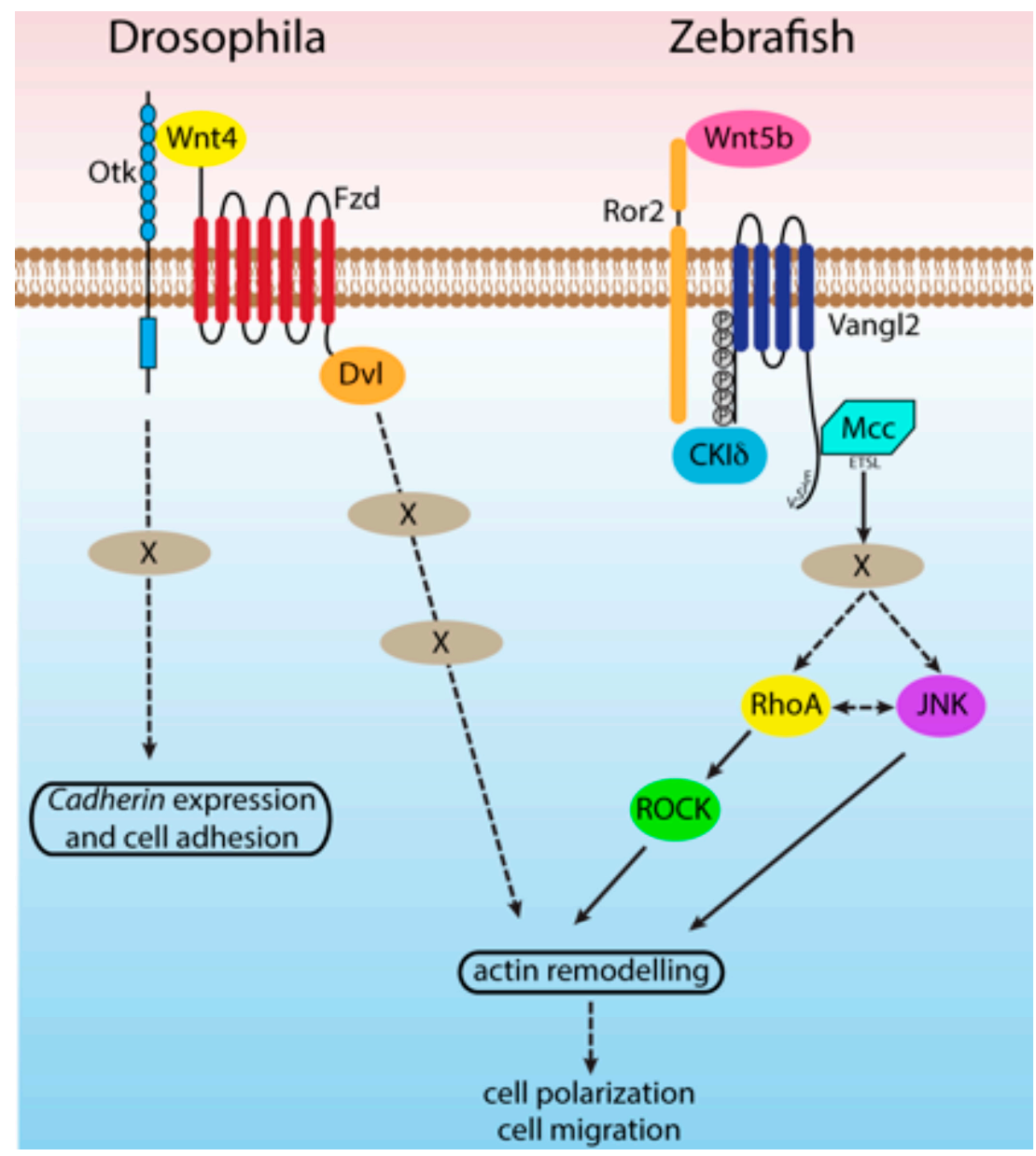

Figure 2. Comparison of the Drosophila and vertebrate non-canonical Wnt pathways applicable to this proposal. The Ptk7/Otk non-canonical Wnt pathway affects several polarity-related signaling molecules, but how direct these effects are is not known. These pathways function through effects on cytoskeleton, adhesion, and subcellular organization.

The specific role of Ptk7 in Wnt signaling remains controversial. Ptk7 recruits the Wnt intracellular effector Disheveled to the membrane, which is a crucial step in Dsh activation (Dsh in Drosophila and Dvl in Vertebrates) $[91,96,97]$. Dsh functions as a critical node in deciding which downstream pathway will be activated, and it appears to be the only Wnt pathway component that is involved in both canonical and non-canonical signaling. In several studies, this interaction leads to non-canonical signaling [94,96], but it can also activate canonical signaling, as a yeast two-hybrid interaction between $\beta$-catenin and Ptk7 was previously observed [98]. It remains unclear how the interaction between $\beta$-catenin and Ptk7 at the membrane activates canonical Wnt signaling, but Ptk7 is clearly required for the formation of the Xenopus Spemann organizer, which has been extensively characterized as reliant on canonical Wnt signaling [98]. In Drosophila, expression of Otk along with Wnt4 inactivates canonical signaling [91]. More controversially, a recent study using newly engineered deletions of otk1 and otk2 in Drosophila found a lack of any embryonic phenotypes casting some doubt on both neuronal pathfinding and Wnt signaling roles for Otk [92]. Clearly, further research will be required to describe the role or roles of Ptk7 in Wnt signaling, but at least in vertebrate systems there is clear evidence for Ptk7 functioning in the network of Wnt signaling pathways [31,72]. 


\section{Role of Mcc}

The gene Mutated in Colorectal Cancer was identified more than 25 years ago through linkage studies and positional cloning as a culprit tumor suppressor gene for colon cancer, as its name implies. Shortly after this initial finding, a now much more famous gene, Adenomatous Polyposis Coli (APC), which is tightly linked to Mcc on human chromosome 5q, was established as the gene responsible for hereditary colon cancer (FAP). As APC grew in prominence, with its binding to $\beta$-catenin first established in 1993 [99], interest in Mcc waned considerably. Several studies have appeared intermittently over the last two decades that have interrogated Mcc function biochemically in various cancer lines, and a few others have slowly emerged supporting a role for Mcc as a bona fide tumor suppressor in some cancers, including colorectal cancer, B cell lymphoma and hepatocellular carcinoma [100-103]. Significantly, Mcc, like its genetic neighbor APC, has also been implicated in WNT signaling, both canonical and non-canonical [104].

Mcc encodes an evolutionarily conserved, multiple PDZ (PSD-95/DLG/ZO-1) domain-containing protein. When overexpressed, Mcc binds $\beta$-catenin in the nucleus to negatively regulate canonical Wnt signaling in cancer cell lines and to inhibit cell proliferation [105,106]. Recently, a yeast two-hybrid screen identified Deleted in Breast Cancer 1 (DBC1) (officially Cell Cycle and Apoptosis Regulator protein 2 (CCAR2)) as an Mcc-interacting protein [107]. Mounting evidence suggests that DBC1 positively regulates $\beta$-catenin activity through the deacetylase SIRT1 [108,109]. Pangon et al. (2015) demonstrate that Mcc overexpression results in the re-localization of DBC1 to the cytoplasm and $\beta$-catenin deacetylation. Irrespective of the molecular mechanism, these data support a model whereby Mcc normally antagonizes canonical, $\beta$-catenin dependent Wnt signaling [107].

A surprising role for Mcc in the non-canonical branch of Wnt signaling emerged from the striking phenotypic similarities between zebrafish embryos depleted of mcc transcripts with antisense morpholinos and previously characterized zebrafish mutants in genes encoding known components of the non-canonical Wnt pathway, including wnt5a/pipetail and vangl2/trilobite/strabismus [104]. Both mcc morphants and these classic mutants show reductions in anterior development, a foreshortened and ventrally curved body axis and tightly packed somites. Such defects originate from impaired convergence and extension movements during gastrulation-the failure of cells to elongate, to orient mediolaterally and to intercalate to lengthen the body axis-and commonly result from the manipulation of $\beta$-catenin independent, non-canonical Wnt signaling. In mice, extensive genetic interactions were previously reported among Wnt5a, Ror2 and Vangl2 null alleles during diverse mammalian CE processes, such as neural tube closure, inner ear hair cell polarity and limb elongation [26], and we reasoned that as a principally cytoplasmic protein Mcc might serve as an intracellular effector of the evolutionarily conserved Wnt5a/Ror2/Vang12 signaling axis during zebrafish CE. Like the PDZ domain-containing protein Disheveled mentioned previously, Mcc indeed physically associates with the Vangl2 cytoplasmic tail, and in epistasis experiments mcc overexpression can rescue the loss of wnt5a, ror 2 or vangl2. How Mcc conveys extracellular Wnt5a signals to the actin cytoskeleton remains unclear, but evidence from zebrafish implicates both Rho and c-Jun N-terminal kinase (Jnk) [104].

\section{Connections between Ptk7 and Mcc}

As mentioned previously, Ptk7 in some signaling contexts engages Fzd7 as a potential co-receptor. Biochemical studies have shown that Vangl2 and Fzd4 form a receptor complex that strongly activates Jnk in vitro [110], and in zebrafish knockdown of $f z d 7 a / b$ results in CE phenotypes largely overlapping with loss of $m c c$, wnt5a, ror2, scrib1, vangl2 as well as ptk7 [67,104,111,112]. Whether multimeric cell surface receptor complexes comprising of Ptk7, Fzd and Vang12 exist is an outstanding question. Moreover, Ptk7 was recently shown to physically interact with Ror2 in vitro, transducing extracellular Wnt5a signals via intracellular Jnk, and not surprisingly Ptk7 and Ror2 cooperate during convergence and extension in Xenopus embryos [94]. Mcc is expressed in the crypts of the adult mouse intestine and recent evidence in both mice and man supports a tumor suppressor role for Mcc in colorectal 
cancer [102,113]. Similarly, Ptk7 is expressed in both the developing gut as well as in the adult intestinal epithelium [114], and there is mounting evidence that Ptk7 dysregulation is associated with the pathogenesis of human gastric and colorectal cancer [115]. Ptk7 is known to interact with PDZ domain containing proteins like Scrib1 in developmental processes such as inner ear PCP [30] and neural tube closure in mice [116], and has been additionally implicated in human neural tube closure defects [117]. Scrib1, much like Mcc contains PDZ domains and is associated with a variety of human cancers [112], suggesting that both could be part of the Wnt non-canonical signaling network. Taken together, these intersecting findings emphasize the complexity of the cell surface permutations available to non-canonical WNT ligands to dictate specific downstream cellular behaviors.

\section{Conclusions}

There are remarkably few signaling pathways that specify the cell types, organs, spatial organization and cellular behavior, during development of complex organisms. Wnt signaling suggests one answer to this conundrum, as it is not one pathway but an amalgamation of many. The study of these sub-pathways through analysis of our example of Ptk7 and Mcc will yield insights into control of cell migration and polarity in the fly, zebrafish and mouse embryo, especially if the various model organism research can be combined to bridge the large evolutionary distances. At present, vanishingly little is known about how extracellular Wnt/PCP ligands lead to the activation of either Ptk7 or Mcc and to remodeling of the actin cytoskeleton, but new experimental approaches such as CRISPR mutagenesis in vertebrates $[68,118,119]$ and the study of morphogenesis in the late Drosophila embryo where PCP, Wnt, and apico-basal polarity come together should lead to new insights [120-128]. Overall, a better understanding of the signaling pathways that mediate cell behavior will not only lead to improved disease treatment, but will enhance our knowledge of how developmental disorders work. In cancer biology, understanding how co-receptors regulate which Wnt outcome results should lead to more targeted therapies that affect only cell proliferation and not homeostatic functions.

Acknowledgments: We thank Prameet Kaur for comments. This work was funded by a grant from the Academic Research Fund MOE2014-T2-2-039 to NST, and by A*Star.

Conflicts of Interest: The authors declare no conflict of interest.

\section{References}

1. Cadigan, K.M.; Nusse, R. Wnt signaling: A common theme in animal development. Genes Dev. 1997, 11, 3286-3305. [CrossRef] [PubMed]

2. Gordon, M.D.; Nusse, R. Wnt signaling: Multiple pathways, multiple receptors, and multiple transcription factors. J. Biol. Chem. 2006, 281, 22429-22433. [CrossRef] [PubMed]

3. Logan, C.Y.; Nusse, R. The Wnt signaling pathway in development and disease. Annu. Rev. Cell Dev. Biol. 2004, 20, 781-810. [CrossRef] [PubMed]

4. Nusse, R. Wnt signaling and stem cell control. Cell Res. 2008, 18, 523-527. [CrossRef] [PubMed]

5. Tolwinski, N.S.; Wieschaus, E. Rethinking WNT signaling. Trends Genet. 2004, 20, 177-181. [CrossRef] [PubMed]

6. Farin, H.F.; Jordens, I.; Mosa, M.H.; Basak, O.; Korving, J.; Tauriello, D.V.; de Punder, K.; Angers, S.; Peters, P.J.; Maurice, M.M.; et al. Visualization of a short-range Wnt gradient in the intestinal stem-cell niche. Nature 2016, 530, 340-343. [CrossRef] [PubMed]

7. Alexandre, C.; Baena-Lopez, A.; Vincent, J.P. Patterning and growth control by membrane-tethered Wingless. Nature 2014, 505, 180-185. [CrossRef] [PubMed]

8. Clevers, H.; Nusse, R. Wnt/ $\beta$-catenin signaling and disease. Cell 2012, 149, 1192-1205. [CrossRef] [PubMed]

9. Nusse, R.; Varmus, H. Three decades of Wnts: A personal perspective on how a scientific field developed. EMBO J. 2012, 31, 2670-2684. [PubMed]

10. Clevers, H.; Loh, K.M.; Nusse, R. Stem cell signaling. An integral program for tissue renewal and regeneration: Wnt signaling and stem cell control. Science 2014. [CrossRef] 
11. Zhu, N.; Qin, L.; Luo, Z.; Guo, Q.; Yang, L.; Liao, D. Challenging role of Wnt5a and its signaling pathway in cancer metastasis (Review). Exp. Ther. Med. 2014, 8, 3-8. [CrossRef] [PubMed]

12. Su, L.K.; Kinzler, K.W.; Vogelstein, B.; Preisinger, A.C.; Moser, A.R.; Luongo, C.; Gould, K.A.; Dove, W.F. Multiple intestinal neoplasia caused by a mutation in the murine homolog of the APC gene. Science 1992, 256, 668-670. [CrossRef] [PubMed]

13. Kinzler, K.W.; Nilbert, M.C.; Su, L.K.; Vogelstein, B.; Bryan, T.M.; Levy, D.B.; Smith, K.J.; Preisinger, A.C.; Hedge, P.; McKechnie, D.; et al. Identification of FAP locus genes from chromosome 5q21. Science 1991, 253, 661-665. [CrossRef] [PubMed]

14. Nakamura, Y.; Nishisho, I.; Kinzler, K.W.; Vogelstein, B.; Miyoshi, Y.; Miki, Y.; Ando, H.; Horii, A. Mutations of the APC (adenomatous polyposis coli) gene in FAP (familial polyposis coli) patients and in sporadic colorectal tumors. Tohoku J. Exp. Med. 1992, 168, 141-147. [CrossRef] [PubMed]

15. Carvajal-Gonzalez, J.M.; Mlodzik, M. Mechanisms of planar cell polarity establishment in Drosophila. F1000Prime Rep. 2014. [CrossRef] [PubMed]

16. Solnica-Krezel, L.; Sepich, D.S. Gastrulation: Making and shaping germ layers. Annu. Rev. Cell Dev. Biol. 2012, 28, 687-717. [CrossRef] [PubMed]

17. Sugimura, R.; Li, L. Noncanonical Wnt signaling in vertebrate development, stem cells, and diseases. Birth Defects Res. C Embryo Today 2010, 90, 243-256. [CrossRef] [PubMed]

18. Zallen, J.A. Planar polarity and tissue morphogenesis. Cell 2007, 129, 1051-1063. [CrossRef] [PubMed]

19. Yang, Y.; Mlodzik, M. Wnt-Frizzled/planar cell polarity signaling: Cellular orientation by facing the wind (Wnt). Annu. Rev. Cell Dev. Biol. 2015, 31, 623-646. [CrossRef] [PubMed]

20. Habib, S.J.; Chen, B.C.; Tsai, F.C.; Anastassiadis, K.; Meyer, T.; Betzig, E.; Nusse, R. A localized Wnt signal orients asymmetric stem cell division in vitro. Science 2013, 339, 1445-1448. [CrossRef] [PubMed]

21. Wu, J.; Roman, A.C.; Carvajal-Gonzalez, J.M.; Mlodzik, M. Wg and Wnt4 provide long-range directional input to planar cell polarity orientation in Drosophila. Nat. Cell Biol. 2013, 15, 1045-1055. [CrossRef] [PubMed]

22. Yu, M.; Ting, D.T.; Stott, S.L.; Wittner, B.S.; Ozsolak, F.; Paul, S.; Ciciliano, J.C.; Smas, M.E.; Winokur, D.; Gilman, A.J. RNA sequencing of pancreatic circulating tumour cells implicates WNT signalling in metastasis. Nature 2012, 487, 510-513. [CrossRef] [PubMed]

23. Gujral, T.S.; Chan, M.; Peshkin, L.; Sorger, P.K.; Kirschner, M.W.; MacBeath, G. A noncanonical Frizzled2 pathway regulates epithelial-mesenchymal transition and metastasis. Cell 2014, 159, 844-856. [CrossRef] [PubMed]

24. Anastas, J.N.; Moon, R.T. WNT signalling pathways as therapeutic targets in cancer. Nat. Rev. Cancer 2013, 13, 11-26. [CrossRef] [PubMed]

25. Luga, V.; Zhang, L.; Viloria-Petit, A.M.; Ogunjimi, A.A.; Inanlou, M.R.; Chiu, E.; Buchanan, M.; Hosein, A.N.; Basik, M.; Wrana, J.L. Exosomes mediate stromal mobilization of autocrine Wnt-PCP signaling in breast cancer cell migration. Cell 2012, 151, 1542-1556. [CrossRef] [PubMed]

26. Gao, B. Wnt regulation of Planar Cell Polarity (PCP). Curr. Top. Dev. Biol. 2012, 101, 263-295. [PubMed]

27. Schlessinger, K.; Hall, A.; Tolwinski, N. Wnt signaling pathways meet Rho GTPases. Genes Dev. 2009, 23, 265-277. [CrossRef] [PubMed]

28. Arias, A.M.; Brown, A.M.; Brennan, K. Wnt signalling: Pathway or network? Curr. Opin. Genet. Dev. 1999, 9, 447-454. [CrossRef]

29. Moon, R.T.; Gough, N.R. Beyond canonical: The Wnt and $\beta$-catenin story. Sci. Signal 2016. [CrossRef] [PubMed]

30. May-Simera, H.; Kelley, M.W. Planar cell polarity in the inner ear. Curr. Top. Dev. Biol. 2012, 101, 111-140. [PubMed]

31. Peradziryi, H.; Tolwinski, N.S.; Borchers, A. The many roles of PTK7: A versatile regulator of cell-cell communication. Arch. Biochem. Biophys. 2012, 524, 71-76. [CrossRef] [PubMed]

32. Lander, R.; Petersen, C. Wnt, Ptk7, and FGFRL expression gradients control trunk positional identity in planarian regeneration. Elife 2016, 5, e12850. [CrossRef] [PubMed]

33. Winberg, M.L.; Tamagnone, L.; Bai, J.; Comoglio, P.M.; Montell, D.; Goodman, C.S. The transmembrane protein Off-track associates with Plexins and functions downstream of Semaphorin signaling during axon guidance. Neuron 2001, 32, 53-62. [CrossRef]

34. Cafferty, P.; Yu, L.; Rao, Y. The receptor tyrosine kinase off-track is required for layer-specific neuronal connectivity in Drosophila. Development 2004, 131, 5287-5295. [CrossRef] [PubMed] 
35. Oliva, C.; Molina-Fernandez, C.; Maureira, M.; Candia, N.; Lopez, E.; Hassan, B.; Aerts, S.; Canovas, J.; Olguin, P.; Sierralta, J. Hindsight regulates photoreceptor axon targeting through transcriptional control of jitterbug/Filamin and multiple genes involved in axon guidance in Drosophila. Dev. Neurobiol. 2015, 75, 1018-1032. [CrossRef] [PubMed]

36. Mossie, K.; Jallal, B.; Alves, F.; Sures, I.; Plowman, G.D.; Ullrich, A. Colon carcinoma kinase-4 defines a new subclass of the receptor tyrosine kinase family. Oncogene 1995, 11, 2179-2184. [PubMed]

37. Park, S.K.; Lee, H.S.; Lee, S.T. Characterization of the human full-length PTK7 cDNA encoding a receptor protein tyrosine kinase-like molecule closely related to chick KLG. J. Biochem. 1996, 119, 235-239. [CrossRef] [PubMed]

38. Chen, R.; Khatri, P.; Mazur, P.K.; Polin, M.; Zheng, Y.; Vaka, D.; Hoang, C.D.; Shrager, J.; Xu, Y.; Vicent, S.; et al. A meta-analysis of lung cancer gene expression identifies PTK7 as a survival gene in lung adenocarcinoma. Cancer Res. 2014, 74, 2892-2902. [CrossRef] [PubMed]

39. Kim, J.H.; Kwon, J.; Lee, H.W.; Kang, M.C.; Yoon, H.J.; Lee, S.T.; Park, J.H. Protein tyrosine kinase 7 plays a tumor suppressor role by inhibiting ERK and AKT phosphorylation in lung cancer. Oncol. Rep. 2014, 31, 2708-2712. [CrossRef] [PubMed]

40. Lin, Y.; Zhang, L.H.; Wang, X.H.; Xing, X.F.; Cheng, X.J.; Dong, B.; Hu, Y.; Du, H.; Li, Y.A.; Zhu, Y.B.; et al. PTK7 as a novel marker for favorable gastric cancer patient survival. J. Surg. Oncol. 2012, 106, 880-886. [CrossRef] [PubMed]

41. Kapoor, S. Emerging new prognostic markers of gastric tumors besides PTK7. J. Surg. Oncol. 2013. [CrossRef] [PubMed]

42. Jung, P.; Sommer, C.; Barriga, F.M.; Buczacki, S.J.; Hernando-Momblona, X.; Sevillano, M.; Duran-Frigola, M.; Aloy, P.; Selbach, M.; Winton, D.J.; et al. Isolation of human colon stem cells using surface expression of PTK7. Stem Cell Rep. 2015, 5, 979-987. [CrossRef] [PubMed]

43. Shinmura, K.; Kiyose, S.; Nagura, K.; Igarashi, H.; Inoue, Y.; Nakamura, S.; Maeda, M.; Baba, M.; Konno, H.; Sugimura, H. TNK2 gene amplification is a novel predictor of a poor prognosis in patients with gastric cancer. J. Surg. Oncol. 2014, 109, 189-197. [CrossRef] [PubMed]

44. Easty, D.J.; Mitchell, P.J.; Patel, K.; Florenes, V.A.; Spritz, R.A.; Bennett, D.C. Loss of expression of receptor tyrosine kinase family genes PTK7 and SEK in metastatic melanoma. Int. J. Cancer 1997, 71, 1061-1065. [CrossRef]

45. Wang, H.; Li, G.; Yin, Y.; Wang, J.; Wang, H.; Wei, W.; Guo, Q.; Ma, H.; Shi, Q.; Zhou, X.; et al. PTK7 protein is decreased in epithelial ovarian carcinomas with poor prognosis. Int. J. Clin. Exp. Pathol. 2014, 7, 7881-7889. [PubMed]

46. Asad, M.; Wong, M.K.; Tan, T.Z.; Choolani, M.; Low, J.; Mori, S.; Virshup, D.; Thiery, J.P.; Huang, R.Y. FZD7 drives in vitro aggressiveness in Stem-A subtype of ovarian cancer via regulation of non-canonical Wnt/PCP pathway. Cell Death Dis. 2014. [CrossRef] [PubMed]

47. Ataseven, B.; Angerer, R.; Kates, R.; Gunesch, A.; Knyazev, P.; Hogel, B.; Becker, C.; Eiermann, W.; Harbeck, N. PTK7 expression in triple-negative breast cancer. Anticancer Res. 2013, 33, 3759-3763. [PubMed]

48. Ataseven, B.; Gunesch, A.; Eiermann, W.; Kates, R.E.; Hogel, B.; Knyazev, P.; Ullrich, A.; Harbeck, N. PTK7 as a potential prognostic and predictive marker of response to adjuvant chemotherapy in breast cancer patients, and resistance to anthracycline drugs. Onco Targets Ther. 2014, 7, 1723-1731. [CrossRef] [PubMed]

49. Gartner, S.; Gunesch, A.; Knyazeva, T.; Wolf, P.; Hogel, B.; Eiermann, W.; Ullrich, A.; Knyazev, P.; Ataseven, B. PTK 7 is a transforming gene and prognostic marker for breast cancer and nodal metastasis involvement. PLoS ONE 2014, 9, e84472. [CrossRef] [PubMed]

50. Prebet, T.; Lhoumeau, A.C.; Arnoulet, C.; Aulas, A.; Marchetto, S.; Audebert, S.; Puppo, F.; Chabannon, C.; Sainty, D.; Santoni, M.J.; et al. The cell polarity PTK7 receptor acts as a modulator of the chemotherapeutic response in acute myeloid leukemia and impairs clinical outcome. Blood 2010, 116, 2315-2323. [CrossRef] [PubMed]

51. Jiang, G.; Zhang, M.; Yue, B.; Yang, M.; Carter, C.; Al-Quran, S.Z.; Li, B.; Li, Y. PTK7: A new biomarker for immunophenotypic characterization of maturing $\mathrm{T}$ cells and $\mathrm{T}$ cell acute lymphoblastic leukemia. Leuk. Res. 2012, 36, 1347-1353. [CrossRef] [PubMed]

52. Zhang, G.T.; Zhang, A.Q. PTK7 mRNA and protein expression level in serum of patients with acute lymphocytic leukemia and its clinical significance. Zhongguo Shi Yan Xue Ye Xue Za Zhi 2014, 22, 1222-1225. [PubMed] 
53. Zhou, H.; Ge, Y.; Sun, L.; Ma, W.; Wu, J.; Zhang, X.; Hu, X.; Eaves, C.J.; Wu, D.; Zhao, Y. Growth arrest specific 2 is up-regulated in chronic myeloid leukemia cells and required for their growth. PLoS ONE 2014, 9, e86195. [CrossRef] [PubMed]

54. Wang, Y. Wnt/Planar cell polarity signaling: A new paradigm for cancer therapy. Mol. Cancer Ther. 2009, 8, 2103-2109. [CrossRef] [PubMed]

55. Kiyose, S.; Nagura, K.; Tao, H.; Igarashi, H.; Yamada, H.; Goto, M.; Maeda, M.; Kurabe, N.; Suzuki, M.; Tsuboi, M.; et al. Detection of kinase amplifications in gastric cancer archives using fluorescence in situ hybridization. Pathol. Int. 2012, 62, 477-484. [CrossRef] [PubMed]

56. Na, H.W.; Shin, W.S.; Ludwig, A.; Lee, S.T. The cytosolic domain of protein-tyrosine kinase 7 (PTK7), generated from sequential cleavage by a disintegrin and metalloprotease 17 (ADAM17) and gamma-secretase, enhances cell proliferation and migration in colon cancer cells. J. Biol. Chem. 2012, 287, 25001-25009. [CrossRef] [PubMed]

57. Zhao, W.; Cui, C.H.; Bose, S.; Guo, D.; Shen, C.; Wong, W.P.; Halvorsen, K.; Farokhzad, O.C.; Teo, G.S.; Phillips, J.A.; et al. Bioinspired multivalent DNA network for capture and release of cells. Proc. Natl. Acad. Sci. USA 2012, 109, 19626-19631. [CrossRef] [PubMed]

58. Bernhard, O.K.; Greening, D.W.; Barnes, T.W.; Ji, H.; Simpson, R.J. Detection of cadherin-17 in human colon cancer LIM1215 cell secretome and tumour xenograft-derived interstitial fluid and plasma. Biochim. Biophys. Acta 2013, 1834, 2372-2379. [CrossRef] [PubMed]

59. Colli, L.M.; Saggioro, F.; Serafini, L.N.; Camargo, R.C.; Machado, H.R.; Moreira, A.C.; Antonini, S.R.; de Castro, M. Components of the canonical and non-canonical Wnt pathways are not mis-expressed in pituitary tumors. PLoS ONE 2013, 8, e62424. [CrossRef] [PubMed]

60. Shin, W.S.; Kwon, J.; Lee, H.W.; Kang, M.C.; Na, H.W.; Lee, S.T.; Park, J.H. Oncogenic role of protein tyrosine kinase 7 in esophageal squamous cell carcinoma. Cancer Sci. 2013, 104, 1120-1126. [CrossRef] [PubMed]

61. Golubkov, V.S.; Strongin, A.Y. Downstream signaling and genome-wide regulatory effects of PTK7 pseudokinase and its proteolytic fragments in cancer cells. Cell Commun. Signal. 2014. [CrossRef] [PubMed]

62. Zhang, H.; Wang, A.; Qi, S.; Cheng, S.; Yao, B.; Xu, Y. Protein tyrosine kinase 7 (PTK7) as a predictor of lymph node metastases and a novel prognostic biomarker in patients with prostate cancer. Int. J. Mol. Sci. 2014, 15, 11665-11677. [CrossRef] [PubMed]

63. Lu, X.; Borchers, A.G.; Jolicoeur, C.; Rayburn, H.; Baker, J.C.; Tessier-Lavigne, M. PTK7/CCK-4 is a novel regulator of planar cell polarity in vertebrates. Nature 2004, 430, 93-98. [CrossRef] [PubMed]

64. Wang, M.; De Marco, P.; Merello, E.; Drapeau, P.; Capra, V.; Kibar, Z. Role of the planar cell polarity gene Protein tyrosine kinase 7 in neural tube defects in humans. Birth Defects Res. A Clin. Mol. Teratol. 2015, 103, 1021-1027. [CrossRef] [PubMed]

65. Caddy, J.; Wilanowski, T.; Darido, C.; Dworkin, S.; Ting, S.B.; Zhao, Q.; Rank, G.; Auden, A.; Srivastava, S.; Papenfuss, T.A.; et al. Epidermal wound repair is regulated by the planar cell polarity signaling pathway. Dev. Cell 2010, 19, 138-147. [CrossRef] [PubMed]

66. Yen, W.W.; Williams, M.; Periasamy, A.; Conaway, M.; Burdsal, C.; Keller, R.; Lu, X.; Sutherland, A. PTK7 is essential for polarized cell motility and convergent extension during mouse gastrulation. Development 2009, 136, 2039-2048. [CrossRef] [PubMed]

67. Hayes, M.; Naito, M.; Daulat, A.; Angers, S.; Ciruna, B. Ptk7 promotes non-canonical Wnt/PCP-mediated morphogenesis and inhibits Wnt/ $\beta$-catenin-dependent cell fate decisions during vertebrate development. Development 2013, 140, 1807-1818. [CrossRef] [PubMed]

68. Grimes, D.T.; Boswell, C.W.; Morante, N.F.; Henkelman, R.M.; Burdine, R.D.; Ciruna, B. Zebrafish models of idiopathic scoliosis link cerebrospinal fluid flow defects to spine curvature. Science 2016, 352, 1341-1344. [CrossRef] [PubMed]

69. Hayes, M.; Gao, X.; Yu, L.X.; Paria, N.; Henkelman, R.M.; Wise, C.A.; Ciruna, B. PTK7 mutant zebrafish models of congenital and idiopathic scoliosis implicate dysregulated Wnt signalling in disease. Nat. Commun. 2014. [CrossRef] [PubMed]

70. Wagner, G.; Peradziryi, H.; Wehner, P.; Borchers, A. PlexinA1 interacts with PTK7 and is required for neural crest migration. Biochem. Biophys. Res. Commun. 2010, 402, 402-407. [CrossRef] [PubMed]

71. Podleschny, M.; Grund, A.; Berger, H.; Rollwitz, E.; Borchers, A. A PTK7/Ror2 co-receptor complex affects xenopus neural crest migration. PLoS ONE 2015, 10, e0145169. [CrossRef] [PubMed] 
72. Onishi, K.; Hollis, E.; Zou, Y. Axon guidance and injury-Lessons from Wnts and Wnt signaling. Curr. Opin. Neurobiol. 2014, 27, 232-240. [CrossRef] [PubMed]

73. Golubkov, V.S.; Aleshin, A.E.; Strongin, A.Y. Potential relation of aberrant proteolysis of human protein tyrosine kinase 7 (PTK7) chuzhoi by membrane type 1 matrix metalloproteinase (MT1-MMP) to congenital defects. J. Biol. Chem. 2011, 286, 20970-20976. [CrossRef] [PubMed]

74. Golubkov, V.S.; Chekanov, A.V.; Cieplak, P.; Aleshin, A.E.; Chernov, A.V.; Zhu, W.; Radichev, I.A.; Zhang, D.; Dong, P.D.; Strongin, A.Y. The Wnt/planar cell polarity protein-tyrosine kinase-7 (PTK7) is a highly efficient proteolytic target of membrane type-1 matrix metalloproteinase: Implications in cancer and embryogenesis. J. Biol. Chem. 2010, 285, 35740-35749. [CrossRef] [PubMed]

75. Golubkov, V.S.; Prigozhina, N.L.; Zhang, Y.; Stoletov, K.; Lewis, J.D.; Schwartz, P.E.; Hoffman, R.M.; Strongin, A.Y. Protein-tyrosine pseudokinase 7 (PTK7) directs cancer cell motility and metastasis. J. Biol. Chem. 2014, 29, 24238-24249. [CrossRef] [PubMed]

76. Golubkov, V.S.; Strongin, A.Y. Insights into ectodomain shedding and processing of protein-tyrosine pseudokinase 7 (PTK7). J. Biol. Chem. 2012, 287, 42009-42018. [CrossRef] [PubMed]

77. Lhoumeau, A.-C.; Arcangeli, M.-L.; de Grandis, M.; Giordano, M.; Orsoni, J.-C.; Lembo, F.; Bardin, F.; Marchetto, S.; Aurrand-Lions, M.; Borg, J.-P. Ptk7-deficient mice have decreased hematopoietic stem cell pools as a result of deregulated proliferation and migration. J. Immunol. 2016, 196, 4367-4377. [CrossRef] [PubMed]

78. Reya, T.; Clevers, H. Wnt signalling in stem cells and cancer. Nature 2005, 434, 843-850. [CrossRef] [PubMed]

79. Nusse, R.; Varmus, H.E. Many tumors induced by the mouse mammary tumor virus contain a provirus integrated in the same region of the host genome. Cell 1982, 31, 99-109. [CrossRef]

80. Nusse, R.; Varmus, H.E. Wnt genes. Cell 1992, 69, 1073-1087. [CrossRef]

81. Kikuchi, A.; Yamamoto, H.; Sato, A.; Matsumoto, S. Wnt5a: Its signalling, functions and implication in diseases. Acta Physiol. 2012, 204, 17-33. [CrossRef] [PubMed]

82. Takigawa, Y.; Brown, A.M. Wnt signaling in liver cancer. Curr. Drug Targets 2008, 9, 1013-1024. [CrossRef] [PubMed]

83. Van Amerongen, R.; Mikels, A.; Nusse, R. Alternative wnt signaling is initiated by distinct receptors. Sci. Signal. 2008. [CrossRef] [PubMed]

84. Green, J.; Nusse, R.; van Amerongen, R. The role of Ryk and Ror receptor tyrosine kinases in Wnt signal transduction. Cold Spring Harb. Perspect. Biol. 2014. [CrossRef] [PubMed]

85. Van Amerongen, R.; Nusse, R. Towards an integrated view of Wnt signaling in development. Development 2009, 136, 3205-3214. [CrossRef] [PubMed]

86. Niehrs, C. The complex world of WNT receptor signalling. Nat. Rev. Mol. Cell Biol. 2012, 13, 767-779. [CrossRef] [PubMed]

87. Yoshikawa, S.; McKinnon, R.D.; Kokel, M.; Thomas, J.B. Wnt-mediated axon guidance via the Drosophila Derailed receptor. Nature 2003, 422, 583-588. [CrossRef] [PubMed]

88. Green, J.L.; Inoue, T.; Sternberg, P.W. Opposing Wnt pathways orient cell polarity during organogenesis. Cell 2008, 134, 646-656. [CrossRef] [PubMed]

89. Tamai, K.; Semenov, M.; Kato, Y.; Spokony, R.; Liu, C.; Katsuyama, Y.; Hess, F.; Saint-Jeannet, J.P.; He, X. LDL-receptor-related proteins in Wnt signal transduction. Nature 2000, 407, 530-535. [PubMed]

90. Wehrli, M.; Dougan, S.T.; Caldwell, K.; O'Keefe, L.; Schwartz, S.; Vaizel-Ohayon, D.; Schejter, E.; Tomlinson, A.; DiNardo, S. Arrow encodes an LDL-receptor-related protein essential for Wingless signalling. Nature 2000, 407, 527-530. [PubMed]

91. Peradziryi, H.; Kaplan, N.A.; Podleschny, M.; Liu, X.; Wehner, P.; Borchers, A.; Tolwinski, N.S. PTK7/Otk interacts with Wnts and inhibits canonical Wnt signalling. EMBO J. 2011, 30, 3729-3740. [CrossRef] [PubMed]

92. Linnemannstons, K.; Ripp, C.; Honemann-Capito, M.; Brechtel-Curth, K.; Hedderich, M.; Wodarz, A. The PTK7-related transmembrane proteins off-track and off-track 2 are co-receptors for Drosophila Wnt2 required for male fertility. PLoS Genet. 2014, 10, e1004443. [CrossRef] [PubMed]

93. Bin-Nun, N.; Lichtig, H.; Malyarova, A.; Levy, M.; Elias, S.; Frank, D. PTK7 modulates Wnt signaling activity via LRP6. Development 2014, 141, 410-421. [CrossRef] [PubMed]

94. Martinez, S.; Scerbo, P.; Giordano, M.; Daulat, A.M.; Lhoumeau, A.C.; Thome, V.; Kodjabachian, L.; Borg, J.P. The PTK7 and ROR2 protein receptors interact in the vertebrate WNT/planar cell polarity (PCP) pathway. J. Biol. Chem. 2015, 290, 30562-30572. [PubMed] 
95. Miyoshi, H.; Ajima, R.; Luo, C.T.; Yamaguchi, T.P.; Stappenbeck, T.S. Wnt5a potentiates TGF- $\beta$ signaling to promote colonic crypt regeneration after tissue injury. Science 2012, 338, 108-113. [CrossRef] [PubMed]

96. Shnitsar, I.; Borchers, A. PTK7 recruits dsh to regulate neural crest migration. Development 2008, 135, 4015-4024. [CrossRef] [PubMed]

97. Fiedler, M.; Mendoza-Topaz, C.; Rutherford, T.J.; Mieszczanek, J.; Bienz, M. Dishevelled interacts with the DIX domain polymerization interface of Axin to interfere with its function in down-regulating $\beta$-catenin. Proc. Natl. Acad. Sci. USA 2011, 108, 1937-1942. [CrossRef] [PubMed]

98. Puppo, F.; Thome, V.; Lhoumeau, A.C.; Cibois, M.; Gangar, A.; Lembo, F.; Belotti, E.; Marchetto, S.; Lecine, P.; Prebet, T.; et al. Protein tyrosine kinase 7 has a conserved role in Wnt/ $\beta$-catenin canonical signalling. EMBO Rep. 2011, 12, 43-49. [CrossRef] [PubMed]

99. Rubinfeld, B.; Souza, B.; Albert, I.; Muller, O.; Chamberlain, S.H.; Masiarz, F.R.; Munemitsu, S.; Polakis, P. Association of the APC gene product with $\beta$-catenin. Science 1993, 262, 1731-1734. [CrossRef] [PubMed]

100. Edwards, S.K.; Baron, J.; Moore, C.R.; Liu, Y.; Perlman, D.H.; Hart, R.P.; Xie, P. Mutated in colorectal cancer (MCC) is a novel oncogene in B lymphocytes. J. Hematol. Oncol. 2014. [CrossRef] [PubMed]

101. Shukla, R.; Upton, K.R.; Munoz-Lopez, M.; Gerhardt, D.J.; Fisher, M.E.; Nguyen, T.; Brennan, P.M.; Baillie, J.K.; Collino, A.; Ghisletti, S.; et al. Endogenous retrotransposition activates oncogenic pathways in hepatocellular carcinoma. Cell 2013, 153, 101-111. [CrossRef] [PubMed]

102. Starr, T.K.; Allaei, R.; Silverstein, K.A.; Staggs, R.A.; Sarver, A.L.; Bergemann, T.L.; Gupta, M.; O'Sullivan, M.G.; Matise, I.; Dupuy, A.J.; et al. A transposon-based genetic screen in mice identifies genes altered in colorectal cancer. Science 2009, 323, 1747-1750. [CrossRef] [PubMed]

103. Lim, L.; Balakrishnan, A.; Huskey, N.; Jones, K.D.; Jodari, M.; Ng, R.; Song, G.; Riordan, J.; Anderton, B.; Cheung, S.T.; et al. MicroRNA-494 within an oncogenic microRNA megacluster regulates G1/S transition in liver tumorigenesis through suppression of mutated in colorectal cancer. Hepatology 2014, 59, 202-215. [CrossRef] [PubMed]

104. Young, T.; Poobalan, Y.; Tan, E.K.; Tao, S.; Ong, S.; Wehner, P.; Schwenty-Lara, J.; Lim, C.Y.; Sadasivam, A.; Lovatt, M.; et al. The PDZ domain protein Mcc is a novel effector of non-canonical Wnt signaling during convergence and extension in zebrafish. Development 2014, 141, 3505-3516. [CrossRef] [PubMed]

105. Fukuyama, R.; Niculaita, R.; Ng, K.P.; Obusez, E.; Sanchez, J.; Kalady, M.; Aung, P.P.; Casey, G.; Sizemore, N. Mutated in colorectal cancer, a putative tumor suppressor for serrated colorectal cancer, selectively represses $\beta$-catenin-dependent transcription. Oncogene 2008, 27, 6044-6055. [CrossRef] [PubMed]

106. Matsumine, A.; Senda, T.; Baeg, G.H.; Roy, B.C.; Nakamura, Y.; Noda, M.; Toyoshima, K.; Akiyama, T. MCC, a cytoplasmic protein that blocks cell cycle progression from the G0/G1 to S phase. J. Biol. Chem. 1996, 271, 10341-10346. [PubMed]

107. Pangon, L.; Mladenova, D.; Watkins, L.; Van Kralingen, C.; Currey, N.; Al-Sohaily, S.; Lecine, P.; Borg, J.P.; Kohonen-Corish, M.R. MCC inhibits $\beta$-catenin transcriptional activity by sequestering DBC1 in the cytoplasm. Int. J. Cancer 2015, 136, 55-64. [CrossRef] [PubMed]

108. Firestein, R.; Blander, G.; Michan, S.; Oberdoerffer, P.; Ogino, S.; Campbell, J.; Bhimavarapu, A.; Luikenhuis, S.; de Cabo, R.; Fuchs, C.; et al. The SIRT1 deacetylase suppresses intestinal tumorigenesis and colon cancer growth. PLoS ONE 2008, 3, e2020. [CrossRef] [PubMed]

109. Srisuttee, R.; Koh, S.S.; Kim, S.J.; Malilas, W.; Boonying, W.; Cho, I.R.; Jhun, B.H.; Ito, M.; Horio, Y.; Seto, E.; et al. Hepatitis B virus X (HBX) protein upregulates $\beta$-catenin in a human hepatic cell line by sequestering SIRT1 deacetylase. Oncol. Rep. 2012, 28, 276-282. [PubMed]

110. Yao, R.; Natsume, Y.; Noda, T. MAGI-3 is involved in the regulation of the JNK signaling pathway as a scaffold protein for frizzled and Ltap. Oncogene 2004, 23, 6023-6030. [CrossRef] [PubMed]

111. Quesada-Hernandez, E.; Caneparo, L.; Schneider, S.; Winkler, S.; Liebling, M.; Fraser, S.E.; Heisenberg, C.P. Stereotypical cell division orientation controls neural rod midline formation in zebrafish. Curr. Biol. 2010, 20 , 1966-1972. [CrossRef] [PubMed]

112. Humbert, P.O.; Russell, S.M.; Smith, L.; Richardson, H.E. The Scribble-Dlg-Lgl module in cell polarity regulation. In Cell Polarity 1; Springer: Cham, Switzerland, 2015; pp. 65-111.

113. Kohonen-Corish, M.R.J.; Sigglekow, N.D.; Susanto, J.; Chapuis, P.H.; Bokey, E.L.; Dent, O.F.; Chan, C.; Lin, B.P.; Seng, T.J.; Laird, P.W.; et al. Promoter methylation of the mutated in colorectal cancer gene is a frequent early event in colorectal cancer. Oncogene 2007, 26, 4435-4441. [CrossRef] [PubMed] 
114. Jung, J.W.; Shin, S.W.; Song, J.; Lee, S.T. Cloning and characterization of the full-length mouse Ptk7 cDNA encoding a defective receptor protein tyrosine kinase. Gene 2004, 17, 75-84. [CrossRef] [PubMed]

115. Lhoumeau, A.C.; Puppo, F.; Prebet, T.; Kodjabachian, L.; Borg, J.P. PTK7: A cell polarity receptor with multiple facets. Cell Cycle 2011, 10, 1233-1236. [CrossRef] [PubMed]

116. Savory, J.G.; Mansfield, M.; Rijli, F.M.; Lohnes, D. Cdx mediates neural tube closure through transcriptional regulation of the planar cell polarity gene Ptk7. Development 2011, 138, 1361-1370. [CrossRef] [PubMed]

117. Juriloff, D.M.; Harris, M.J. A consideration of the evidence that genetic defects in planar cell polarity contribute to the etiology of human neural tube defects. Birth Defects Res. A Clin. Mol. Teratol. 2012, 94, 824-840. [CrossRef] [PubMed]

118. Steinhart, Z.; Hart, T.; Sidhu, S.; Moffat, J.; Angers, S. Abstract IA13: Inhibiting the Wnt pathway with selective anti-Frizzled synthetic antibodies. Mol. Cancer Res. 2016. [CrossRef]

119. Hart, T.; Chandrashekhar, M.; Aregger, M.; Steinhart, Z.; Brown, K.R.; MacLeod, G.; Mis, M.; Zimmermann, M.; Fradet-Turcotte, A.; Sun, S. High-resolution CRISPR screens reveal fitness genes and genotype-specific cancer liabilities. Cell 2015, 163, 1515-1526. [CrossRef] [PubMed]

120. Walters, J.W.; Munoz, C.; Paaby, A.B.; Dinardo, S. Serrate-Notch signaling defines the scope of the initial denticle field by modulating EGFR activation. Dev. Biol. 2005, 286, 415-426. [CrossRef] [PubMed]

121. Walters, J.W.; Dilks, S.A.; DiNardo, S. Planar polarization of the denticle field in the Drosophila embryo: Roles for Myosin II (zipper) and fringe. Dev. Biol. 2006, 297, 323-339. [CrossRef] [PubMed]

122. Donoughe, S.; DiNardo, S. dachsous and frizzled contribute separately to planar polarity in the Drosophila ventral epidermis. Development 2011, 138, 2751-2759. [CrossRef] [PubMed]

123. Lawlor, K.T.; Ly, D.C.; DiNardo, S. Drosophila dachsous and Fat polarize actin-based protrusions over a restricted domain of the embryonic denticle field. Dev. Biol. 2013, 383, 285-294. [CrossRef] [PubMed]

124. Colosimo, P.F.; Tolwinski, N.S. Wnt, Hedgehog and junctional Armadillo/ $\beta$-catenin establish planar polarity in the Drosophila embryo. PLoS ONE 2006, 1, e9. [CrossRef] [PubMed]

125. Colosimo, P.F.; Liu, X.; Kaplan, N.A.; Tolwinski, N.S. GSK3 $\beta$ affects apical-basal polarity and cell-cell adhesion by regulating aPKC levels. Dev. Dyn. 2010, 239, 115-125. [CrossRef] [PubMed]

126. Kaplan, N.A.; Colosimo, P.F.; Liu, X.; Tolwinski, N.S. Complex interactions between GSK3 and aPKC in Drosophila embryonic epithelial morphogenesis. PLoS ONE 2011, 6, e18616. [CrossRef] [PubMed]

127. Kaplan, N.A.; Liu, X.; Tolwinski, N.S. Epithelial polarity: Interactions between junctions and apical-basal machinery. Genetics 2009, 183, 897-904. [CrossRef] [PubMed]

128. Kaplan, N.A.; Tolwinski, N.S. Spatially defined Dsh-Lgl interaction contributes to directional tissue morphogenesis. J. Cell Sci. 2010, 123, 3157-3165. [CrossRef] [PubMed]

(C) 2016 by the authors; licensee MDPI, Basel, Switzerland. This article is an open access article distributed under the terms and conditions of the Creative Commons Attribution (CC-BY) license (http://creativecommons.org/licenses/by/4.0/). 